\title{
CHARACTERISTICS OF EUGENOL PRODUCTS AND IN VITRO RELEASE IN GEL BASE WITH HYDROXYPROPYL METHYLCELLULOSE (HPMC) VARIANT AS GELLING AGENT
}

\section{SHOLICHAH ROHMANI ${ }^{*}$, ADI YUGATAMA ${ }^{2}$, ISTI WIJAYANTI ${ }^{2}$, DIAN EKA ERMAWATI ${ }^{1}$, ANIF NUR ARTANTI ${ }^{1}$, WISNU KUNDARTO ${ }^{1}$, M. FIQRI ZULPADLY ${ }^{1}$}

\author{
1Department of Pharmacy, Pharmacy Diploma Study Program, Vocational School, Sebelas Maret University, Surakarta, Indonesia, \\ ${ }^{2}$ Department of Pharmacy, Bachelor of Pharmacy Study Program, Faculty of Mathematics and Natural Sciences, Sebelas Maret University, \\ Surakarta, Indonesia \\ Email: licha.apt@gmail.com
}

Received: 08 Jun 2021, Revised and Accepted: 01 Sep 2021

\section{ABSTRACT}

Objective: This research was conducted to examine the characteristics of the eugenol gel preparation in the Hydroxypropyl Methylcellulose (HPMC) gel base and to determine the profile of the release of eugenol from the HPMC gel base.

Methods: Eugenol was made into gel preparations using HPMC base with concentrations of 3\%, 5\% and 7\%. The evaluation included the tests of product characteristic and eugenol release. The product characteristic test included organoleptic examination (texture, color, and odor) and tests of spreadability, adhesion, and $\mathrm{pH}$. The release test was carried out using cell diffusion and cellophane membranes.

Results: All formulas met the $\mathrm{pH}$ requirements of topical products that were safe to use. The spreadability test is between $2.97-6.27 \mathrm{~cm}$, adhesion test of products>4 s. The percentage of determination of eugenol content in the gel formula (F1 105.81\%), (F2 93.28\%) and (F3 98.87\%). The cumulative amount of eugenol was F1 (2.563 mg/cm2), F2 (2.224 mg/cm2), and F3 (1.895 mg/cm2).

Conclusion: The variation of HPMC as a gel base has effects on the adhesion, spreadability, and the eugenol gel release profile, where the greater the HPMC concentration, the smaller the spreadability, the greater the adhesion, and the lower the eugenol release profile. Based on the data obtained, the Formula 1 had a better release rate.

Keywords: Eugenol, Gel, Hydroxypropyl methylcellulose, Release profile

(c) 2021 The Authors. Published by Innovare Academic Sciences Pvt Ltd. This is an open access article under the CC BY license (https://creativecommons.org/licenses/by/4.0/) DOI: https://dx.doi.org/10.22159/ijap.2021v13i6.42351. Journal homepage: https://innovareacademics.in/journals/index.php/ijap

\section{INTRODUCTION}

Eugenol compound is widely researched and developed due to its various efficacies. The biological activities of eugenol are as antifungal, antibacterial, anti-carcinogenic, allergy, antioxidant, antimutagenic, and anti-insecticidal [1]. Apart from being used in the medical field, eugenol is also widely used in industrial field such as industries of food, perfume, agricultural, textile, and others.

To maximize more, the use of eugenol can be formulated into products that can increase the comfort while being used. One form of product that can be made using eugenol is gel. Gel is potentially better as a means of managing topical drugs than ointment, since gel is non-sticky, requires less energy for formulation, stable, and its aesthetic is good [2]. A good gel product can be produced by formulating several types of gelling agents, however, the most important thing to note is the selection of the gelling agent. In gel formulation, the gelling agent component is a critical factor that can affect the physical properties of the gel produced [3]. Hydroxypropyl methylcellulose (HPMC) gel base is the gelling agent often used in the production of cosmetics and medicines since it can produce clear gel, dissolves easily in water, and has low toxicity. In addition, HPMC produces gel that is neutral, clear, colorless, stable at $\mathrm{pH} 3-11$, has good resistance to microbial attack, and provides good film strength when drying on the skin [4]. The results of previous research indicated that HPMC bases had good drug release rate and wide spreadability [2].

The test for the eugenol active substance release of gel base is intended to determine that the optimum product has been made. Several factors that need to be considered when penetrating drugs through the membrane include the type of base, the solubility of the active substance in the base, and the $\mathrm{pH}$ of the base. In vitro release of the active substance from the carrier is a more cost-effective method of characterizing drug absorption and penetration through the skin membrane [5].

However, there has been no study to formulate eugenol in HPMC gel base to compare its drug release profile. This research was conducted to examine the characteristics of eugenol gel preparation in HPMC gel base and to determine the eugenol release from the HPMC gel base. The evaluation included the tests of product characteristic and eugenol release. The product characteristic test included organoleptic examination (texture, color, and odor) and tests of spreadability, adhesion, and $\mathrm{pH}$. The release test was carried out using cell diffusion and cellophane membranes.

\section{MATERIALS AND METHODS}

\section{Materials}

Eugenol (Purchased from Merck, Indonesia), Glycerin (Purchased from Brataco, Indonesia), HPMC (Purchased from Brataco, Indonesia), Propylene glycol (Purchased from Brataco, Indonesia), Nipagin (Purchased from Brataco, Indonesia), distilled water (Purchased from Brataco, Indonesia), $\mathrm{KH}_{2} \mathrm{PO}_{4}$ (Purchased from Merck, Indonesia), $\mathrm{NaOH}$ (Purchased from Merck, Indonesia), Ethanol p. a (Purchased from Merck, Indonesia), Cellophane Membrane (Purchased from Merck, Indonesia).

\section{Formulation}

Method: the HPMC was dispersed in propylene glycol, then added distilled water completely, and stirred until homogeneous and fluffy (mass 1). The nipagin was dissolved in $96 \%$ ethanol, put into the mass 1 , and stirred until homogeneous. The eugenol was dissolved with the remaining $96 \%$ ethanol, and added with propylene glycol, then stirred until dissolved, and then mixed into the base which had been formed, then stirred until homogeneous. 
Table 1: Eugenol gel preparation formula

\begin{tabular}{llll}
\hline Material & Composition (\%) & \\
\cline { 2 - 4 } & F1 & F2 \\
\hline Eugenol & 4 & 4 & \\
HPMC & 3 & 5 & \\
Propylene glykol & 30 & 28 & 7 \\
Ethanol 96\% & 10 & 10 & 26 \\
Nipagin & 0,1 & 0,1 & 10 \\
Aquadest & Ad 100 & Ad 100 & 0,1 \\
\hline
\end{tabular}

\section{Characteristics test}

\section{Organoleptic test}

The organoleptic test was carried out to see the physical appearance of the product by direct observation of the consistency, color, and odor of the gel being made [6].

\section{Homogeneity}

Formulations were tested for homogeneity by visual inspection after the formulations have been set in the container [7].

\section{pH test}

The $\mathrm{pH}$ of prepared gels was measured using a $\mathrm{pH}$ meter [8]. The $\mathrm{pH}$ test was carried out to see the acidity content of the gel product to ensure the gel product did not cause irritation to the skin. The $\mathrm{pH}$ of the gel product was measured using a $\mathrm{pH}$ meter that had been calibrated using a buffer solution of $\mathrm{pH} 4.01$ and $\mathrm{pH} 6.86$ [9]. Based on SNI No.06-2588, the $\mathrm{pH}$ value of the gel product was in the range of 4.5-6.5.

\section{Spreadability test}

The gel was weighed as much as $0.5 \mathrm{~g}$, and then placed in the middle of a scaled round glass. Another round glass or other transparent material and a weight of $200 \mathrm{~g}$ was placed on top of the gel, then it was allowed to stand for $1 \mathrm{~min}$, and the diameter of the spread was recorded [4]. The value of the spreadability test that meets SNI No. $06-2588$ is 5 to $7 \mathrm{~cm}$.

\section{Adhesion test}

The adhesion test was done by placing $0.5 \mathrm{~g}$ of gel on top of the glass object whose width had been determined. Another glass object was placed on top of the gel, and pressed it with a weight of $1 \mathrm{~kg}$ for 5 min. The glass object was attached to the test kit. The $100 \mathrm{~g}$ weight was removed, and recorded the time until the two glass objects were released [10].

\section{Determination of eugenol content in gel}

\section{Base raw curve}

A eugenol stock solution with ethanol solvent was made at 1250 ppm. $1 \mathrm{~g}$ of gel base was dissolved in the stock solution, then $10 \mathrm{ml}$ of ethanol were added. After that, stirred for $15 \mathrm{~min}$, filtered and diluted to several levels of concentration. Three types of raw curves were made according to the gel formula.

\section{Determination of content}

$1 \mathrm{~g}$ of eugenol gel is added with $10 \mathrm{ml}$ of ethanol, then stirred for 15 min at $25{ }^{\circ} \mathrm{C}$, then carried out a dilution according to the absorption range on the standard curve. The dilution results were analyzed using a UV-VIS spectrophotometer at a wavelength of $200-400 \mathrm{~nm}$.

\section{Eugenol release test from the gel base}

In vitro penetration test has been commonly used to measure the rate of drug release to reflect the combination effect of several physical and chemical parameters [11]. The release rate test instrument and equipment for the gel product used was a 5-paddle over disk apparatus, equipped with diffusion cell. Phosphate buffer was used as a dissolution medium, and cellophane as a membrane. The prepared diffusion cell was put into a vessel in the release test instrument containing $500 \mathrm{ml}$ of phosphate buffer solution. The experiment temperature was set at $37^{\circ} \mathrm{C} \pm 0.5^{\circ} \mathrm{C}$. The paddle was rotated at $200 \mathrm{rpm}$. At min 0, 15, 30, 45, 60, 90, 120, 180, 240, 300, 360,420 and 480 , samples of $10 \mathrm{ml}$ were taken. Then the absorption was observed using a UV-Vis spectrophotometer at a wavelength of $283 \mathrm{~nm}$. For each sampling, $10 \mathrm{ml}$ of new phosphate buffer liquid was added for each time unit.

Calculation of the cumulative amount of penetrated eugenol per diffusion area was done using the formula:

$$
\mathrm{Q}=\frac{\mathrm{CnV}+\sum_{\mathrm{i}=1}^{\mathrm{n}-1} \mathrm{Ci} . \mathrm{S}}{\mathrm{A}}
$$

$\mathrm{Q}=$ Cumulative amount of eugenol per diffusion area

$\mathrm{Cn}=$ Concentration of eugenol in the $\mathrm{n}^{\text {th }}$-minute sampling

$\sum_{i=1}^{n-1} c_{t}=$ Total eugenol concentrations in the first sampling until before the $\mathrm{n}^{\text {th }}$ minute

$\mathrm{V}=$ Volume of Diffusion membrane

$\mathrm{S}=$ Sample volume

$\mathrm{A}=$ Area of the membrane

The results obtained were graphed between the penetrated cumulative amounts per diffusion area against the time.

\section{RESULTS AND DISCUSSION}

\section{Gel characteristic test}

Organoleptic

The purpose of the organoleptic test was for simple and subjective initial recognition using the five senses. The observation was made directly by observing the shape, color, and smell of the gel product that had been made.

Table 2: Organoleptic test results for eugenol gel

\begin{tabular}{|c|c|c|c|c|c|c|c|c|c|}
\hline \multirow{2}{*}{$\begin{array}{l}\text { Storage } \\
\text { time }\end{array}$} & \multicolumn{3}{|l|}{ Formula 1} & \multicolumn{3}{|l|}{ Formula 2} & \multicolumn{3}{|l|}{ Formula 3} \\
\hline & Consistensy & Color & Smell & Consistensy & Color & Smell & Consistensy & Color & Smell \\
\hline Week 1 & a little thick & White & $\begin{array}{l}\text { Typical } \\
\text { eugenol }\end{array}$ & Thick & $\begin{array}{l}\text { Pale } \\
\text { white }\end{array}$ & $\begin{array}{l}\text { Typical } \\
\text { eugenol }\end{array}$ & Very thick & $\begin{array}{l}\text { White } \\
\text { yellowish }\end{array}$ & $\begin{array}{l}\text { Typical } \\
\text { eugenol }\end{array}$ \\
\hline Week 2 & a little thick & White & $\begin{array}{l}\text { Typical } \\
\text { eugenol }\end{array}$ & Thick & $\begin{array}{l}\text { Pale } \\
\text { white }\end{array}$ & $\begin{array}{l}\text { Typical } \\
\text { eugenol }\end{array}$ & Very thick & $\begin{array}{l}\text { White } \\
\text { yellowish }\end{array}$ & $\begin{array}{l}\text { Typical } \\
\text { eugenol }\end{array}$ \\
\hline Week 3 & a little thick & White & $\begin{array}{l}\text { Typical } \\
\text { eugenol }\end{array}$ & Thick & $\begin{array}{l}\text { Pale } \\
\text { white }\end{array}$ & $\begin{array}{l}\text { Typical } \\
\text { eugenol }\end{array}$ & Very thick & $\begin{array}{l}\text { White } \\
\text { yellowish }\end{array}$ & $\begin{array}{l}\text { Typical } \\
\text { eugenol }\end{array}$ \\
\hline Week 4 & a little thick & White & $\begin{array}{l}\text { Typical } \\
\text { eugenol }\end{array}$ & Thick & $\begin{array}{l}\text { Pale } \\
\text { white }\end{array}$ & $\begin{array}{l}\text { Typical } \\
\text { eugenol }\end{array}$ & Very thick & $\begin{array}{l}\text { White } \\
\text { yellowish }\end{array}$ & $\begin{array}{l}\text { Typical } \\
\text { eugenol }\end{array}$ \\
\hline
\end{tabular}


Table 3: Homogeneity test results for eugenol gel

\begin{tabular}{llll}
\hline Storage time & Formula 1 & Formula 2 & Formula 3 \\
\hline Week 1 & Homogeneity & Homogeneity & Homogeneity \\
Week 2 & Homogeneity & Homogeneity & Homogeneity \\
Week 3 & Homogeneity & Homogeneity & Homogeneity \\
Week 4 & Homogeneity & Homogeneity & Homogeneity \\
\hline
\end{tabular}

The difference between the three formulas was in the form of the gel since the variation in the concentration of HPMC gave a difference in the form of the resulting gel. The Formula 3 had the thickest product form compared to the Formula 1 and 2. The cause of Formula 3 was the thickest because its HPMC concentration was the biggest.

The homogeneity test aimed to determine the uniformity of the particles of the gel product. The test results showed that all formulas were homogeneous for four weeks of storage by observation using a $40 \times 10$ magnification microscope. The formula can be said to be homogeneous if it meets the requirements for a homogeneous product (gel), that is, if it is applied to a piece of glass or other suitable transparent material, then it should show a homogeneous structure that can be seen in the absence of particles clustered and spread evenly. The even distribution of particles proved that the active substance was evenly distributed in the product; therefore, it would have given maximum results if it had been used.

\section{pH test}

The $\mathrm{pH}$ test aimed to determine whether the gel made was in accordance with the $\mathrm{pH}$ of the skin, therefore it was safe to use. The physiological $\mathrm{pH}$ of the skin is between 4.5-6.5, thus the further the difference between the $\mathrm{pH}$ of the topical product and the physiological $\mathrm{pH}$ (can be higher or lower), the more likely it is to have a negative reaction. Negative reactions can arise because the skin is difficult to neutralize the $\mathrm{pH}$ of the gel, then it will be tired. The negative reactions cause the skin become dry, cracked, sensitive, and easily infected [12].

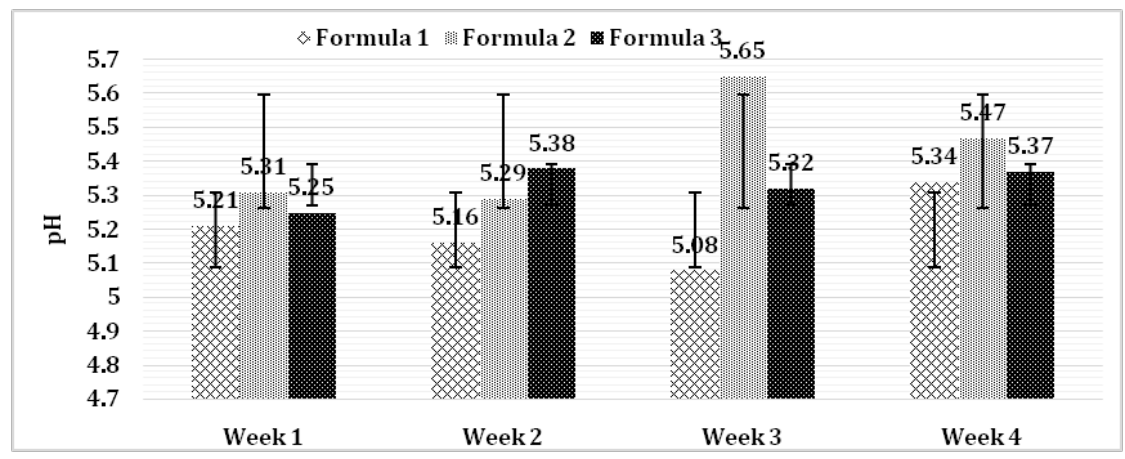

Fig. 1: pH test results for eugenol gel (error bars represent standar deviation for $\mathrm{n}=3$ )

The test results showed that the $\mathrm{pH}$ of Formulas 1,2, and 3 were stable for four weeks of storage, ranging from 5.00 to 5.93 so that it was still included in the skin's physiological $\mathrm{pH}$ range These results are linear with the research on gel formulation with HPMC from Elfasyari et al. (2019) which resulted in a gel $\mathrm{pH}$ of 4.2-6.5 so it can be concluded that the gel made does not irritate the skin and meets the requirements for good physical properties and physical stability parameters [13]. All formulas met the $\mathrm{pH}$ requirements of topical products that were safe to use.

\section{Spreadability test}

The spreadability test was carried out to determine the ability of the gel to spread on the skin surface when applied. The good distribution ability of the gel will provide a more even distribution of the active ingredients on the skin so that the effect of the active ingredients is more optimal.

The difference in the concentration of HPMC in each formula caused a difference in the viscosity of the resulting gel. Gel viscosity is inversely proportional to the spreadability; the higher the concentration of the gelling agent used, the increased resistance of the gel to flow and spread [4]. The higher the gelling agent concentration, the smaller the dispersibility. The results of the dispersion test were stable for four weeks of storage.

\section{Adhesion test}

The adhesion test aimed to determine the time it took to adhere to the skin. The good adhesion allows the drug not to come off easily and the longer it sticks to the skin, so that it can produce the desired effect.

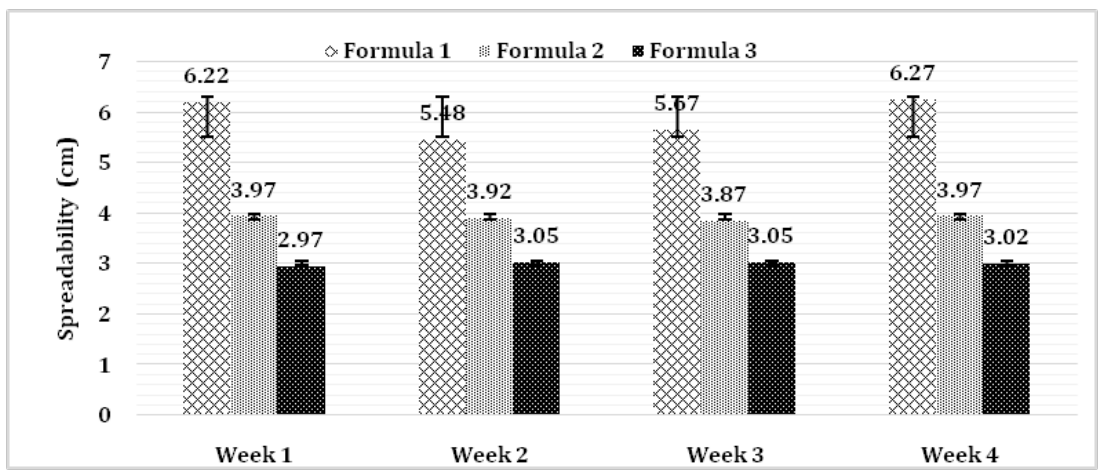

Fig. 2: Spreadability test results for eugenol gel (Error bars represent standar deviation for $n=3$ ) 


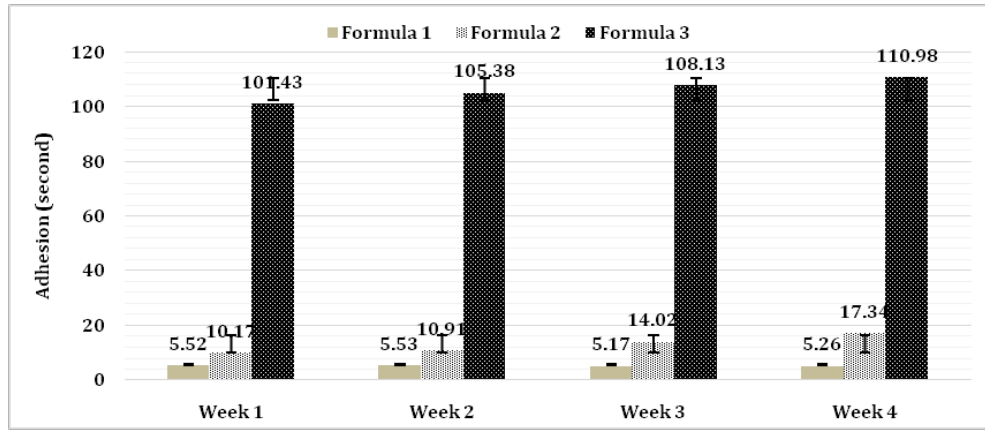

Fig. 3: Adhesion test results for eugenol gel (Error bars represent standar deviation for $n=3$ )

The calculation results of the average adhesion of the three formulas had met the requirements for good adhesion of topical products, namely $>4 \mathrm{~s}$ [14]. The average value of adhesion for each formula had increased, in line with the increase in the HPMC concentration. HPMC (gelling agent) is a non-therapeutic polymer material which functions to control the viscosity of the product being made. The polymer gelling agent will bind to the solvent to form a threedimensional network, where the solvent and solute will be trapped in the polymer network, then the viscosity of the gel will increase [15]. Viscosity causes adhesion to increase because the polymer network increases, therefore more water is trapped in the polymer network which causes the gel to become thicker, thus it takes longer to release when tested for adhesion. Other studies have also stated that the waterier the product, the lesser the adhesion. The higher the viscosity, the thicker the consistency and the greater the stickiness [16].

\section{Determination of eugenol content in gel}

\section{Base raw curve}

This research used the base calibration curve method because, if the gel base provides absorption, it is worried that it will interfere with the results of the content calculation. The standard curve regression results can be seen in fig. 1,2 and 3.

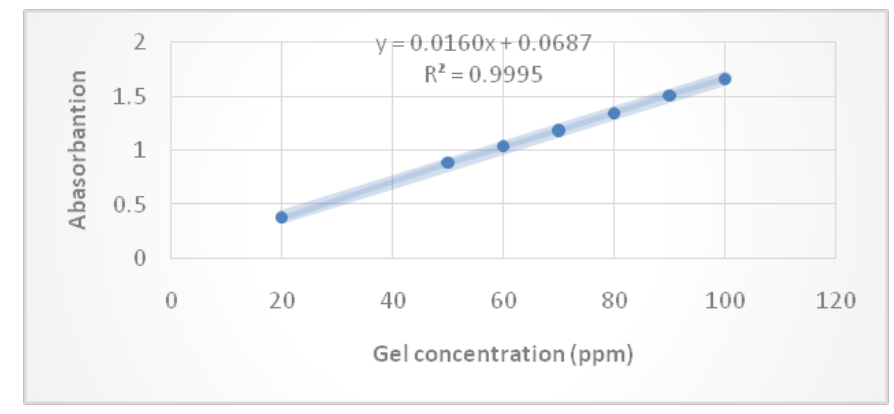

Fig. 4: The standard curve formula 1

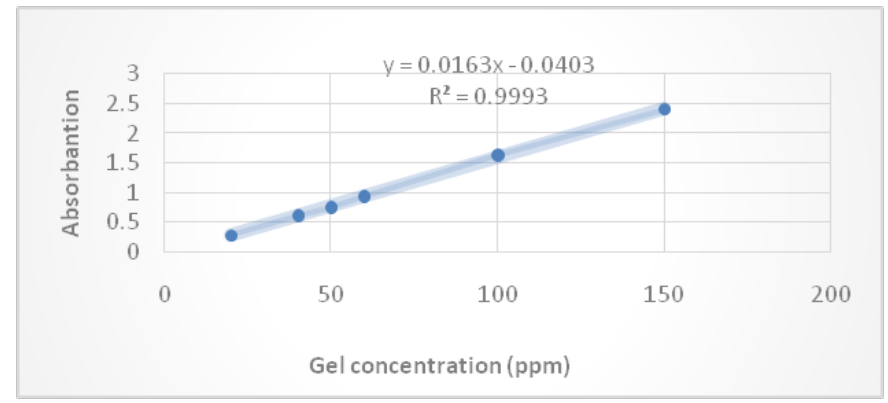

Fig. 5: The standard curve formula 2

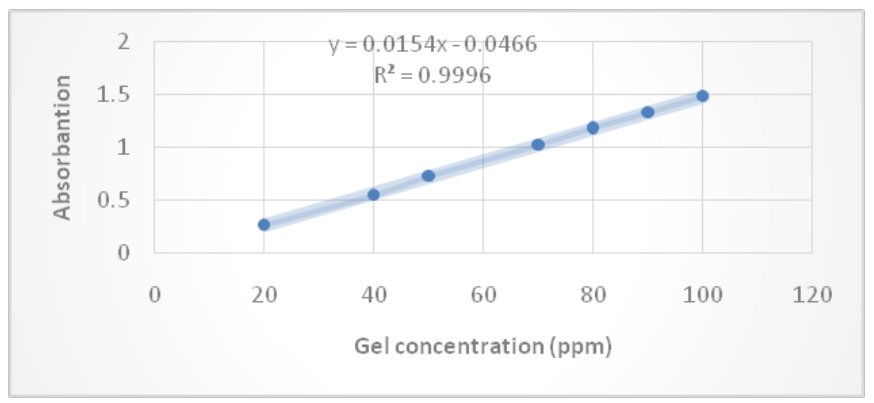

Fig. 6: The standard curve formula 3 
The results of measuring the standard curve in each formula have met the linearity requirements since the value of $r^{2} \geq 0.997$ was obtained [17].

\section{Content determination results}

The percentage of determination of eugenol content in the gel formula obtained a value of $105.81 \%$, the Formula 2 was $93.28 \%$, and the Formula 3 was $98.87 \%$. Based on these results, it can be concluded that the three formulas have met the content requirements since they were in a good level range, which was 80 to $110 \%$ [18].

\section{Release test results}

The release test had several parameters, they were the cumulative amount of released active substance, and the value of released drug flux from the base. Based on the data obtained, the formula that had the largest cumulative amount of eugenol was F1 $(2.563 \mathrm{mg} / \mathrm{cm} 2)$, then F2 $(2.224 \mathrm{mg} / \mathrm{cm} 2)$, and the smallest cumulative amount was F3 (1.895 mg/cm2).

The flux increased in the initial minutes, and this indicated the rapid release of eugenol in the three formulas.

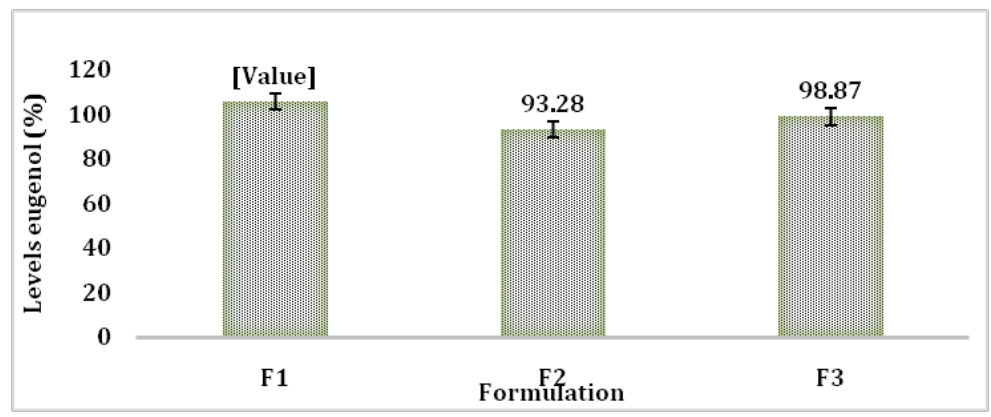

Fig. 7: Eugenol content (Error bars represent standar deviation for $n=3$ )

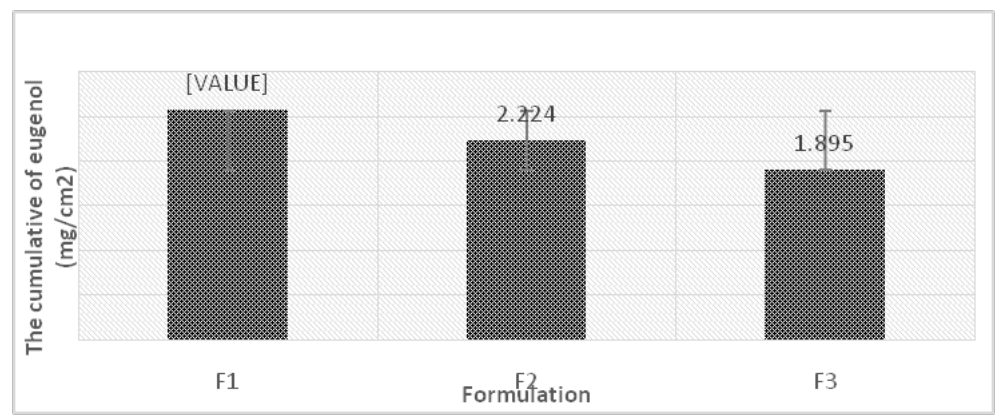

Fig. 8: Cumulative amount of eugenol (Error bars represent standar deviation for $n=3$ )

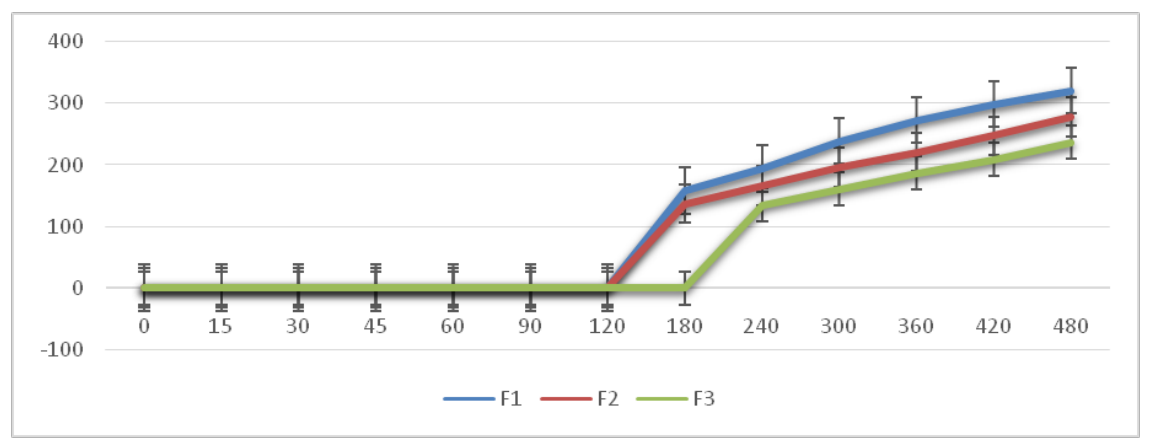

Fig. 9: Eugenol flux curve per minute (Error bars represent standar deviation for $\mathrm{n}=3$ )

This release test aimed to determine the release rate of an active ingredient from the carrier, and also to see how much the active ingredient could penetrate in vitro through the membrane. This diffusion test was carried out for $480 \mathrm{~min}$, by taking $10 \mathrm{ml}$ samples every few minutes; and after that, it was measured in a UV-Vis spectrophotometer.

Table 4: Total eugenol penetrated through in vitro test (release profile)

\begin{tabular}{lll}
\hline Formula & \% eugenol penetrated & CV (\%) \\
\hline 1 & $70,275 \pm 2.044$ & 2.909 \\
2 & $63,045 \pm 2,828$ & 4.485 \\
3 & $53,173 \pm 2,297$ & 4.319 \\
\hline
\end{tabular}

*All values were expressed as (mean $\pm \mathrm{SD}, \mathrm{n}=3$ ) observations 
Based on the data obtained, it can be analyzed that the Formula 1 had a better release rate, characterized by a greater number of active ingredients concentrating through the membrane into the dissolution medium, compared to the other two formulas. The same as previous studies, increasing the concentration of HPMC causes differences in the ability to release the active substance [13]. The factors that affected the rate of penetration of an active ingredient into the skin were: formulation, type of used medium, type of membrane, rotation/movement, and temperature [19]. In addition the formulations, will appear the change of parameters, such as composition, process, equipment, scale-up or scale-down [20].

\section{CONCLUSION}

The variation of Hydroxypropyl Methylcellulose (HPMC) as a gel base has effects on the adhesion, spreadability, and the eugenol gel release profile, where the greater the HPMC concentration, the smaller the spreadability, the greater the adhesion, and the lower the eugenol release profile. In Formula 1 with the smallest concentration of HPMC (3\%), resulted in the largest cumulative amount of eugenol $(2,563 \mathrm{mg} / \mathrm{cm} 2)$, and the total eugenol penetrated through the in vitro test (release profile) was $70.275 \%$

\section{ACKNOWLEDGMENT}

This study was financially supported by Sebelas Maret University Surakarta, Indonesia, through a PKLP grant.

\section{AUTHORS CONTRIBUTIONS}

All authors have contributed equally.

\section{CONFLICTS OF INTERESTS}

No conflict of interest was declared by the authors.

\section{REFERENCES}

1. Daniel AN, Sartoretto SM, Schmidt G, Caparroz-Assef SM, Bersani-Amado CA, Cuman RKN. Anti-inflammatory and antinociceptive activities A of eugenol essential oil in experimental animal models. Rev Bras Farmacogn 2009;19(1b):212-7. doi: 10.1590/S0102695X2009000200006.

2. Madan J, Singh R. Formulation and evaluation of Aloe vera topical gels. Int J Phys Sci. 2010;2:551-5.

3. Arikaumala J, Dewantara IGNA, Wijayanti NPAD. HPMC Optimization as gelling agent in the gel formula of mangosteen peel extract (Garcinia mangostan L.). Udayana J Pharm 2013;2:145-51.

4. Martin A, Swarbrick J, Cammarata A. Physical pharmacy. 2nd. Yoshita. Jakarta: UI Press; 2012.

5. Prabawati CA, editor. Evaluation of penetration power of ethyl P-methoxynamate isolation of Kencur rhizome (Kaempheria galanga L) in ointment, cream and gel preparations [thesis]; 2015.

6. Martin A, Swarbrick J, Cammarata A. Physical pharmacy: list of fundamentals of physical. J Chem Pharm Sci 1993.

7. Jyothi D, Koland M. Formulation and evaluation of an herbal anti-inflammatory gel containing Trigonella foenum greacum seed extract. Int J Pharm Pharm Sci. 2016;8:41-4.

8. Patwardhan SK, Bhide MA. Evaluation of myristica fragrans as a penetration enhancer in transdermal gel formulation. Int J Pharm Pharm Sci. 2015; 7:350-5.

9. Adnan J. Leaf extract gel formulation (PluceaindicaLess) with Na-CMC as a gel base. J Pharma Sci Herbal Tech. 2017;1:41-4.

10. Gallery TI, Astuti DS, Barlian AA. Effect of CMC Na base type on physical quality of Aloe vera extract gel (Aloe vera L.). Pharm Sci;J2016(4):25-9.

11. Ramadon D, Pramesti SS, Anwar E. Formulation, stability tformulation, stability test and in vitro penetration study of transethosomal gel containing green tea (camellia sinensis 1 . kuntze) leaves extractest and in vitro penetration study of transethosomal gel containing green tea(camellia sinensis 1. kuntze) leaves extract. Int J App Pharm. 2017;9(5):91-6. doi: 10.22159/ijap.2017v9i5.20073.

12. Tranggono RI, Latifah F, editors. Handbook of cosmetic science. Jakarta: P T. Gramedia Pustaka Utama; 2007.

13. Elfasyari TY, Putri LR, Wulandari S. Formulation and evaluation of antioxidant gel formulated from jujube (Ziziphus jujuba Mill.) leaves extract. Pharm J Indones. 2019;16:278-85.

14. Rachmalia NIM, Nining S, Tedjo Y. Irritation and physical properties of clove flower (Syzigium Aromaticum) essential oil ointment on hydrocarbon base. Pharm Mag. 2016;12:372-6.

15. Karsheva M, Georgieva S, Handjieva S. The choice of the thickener-A way to improve the cosmetics sensory properties. J Univ Chem Technol Metall. 2007;42:187-94.

16. Nurlaela E, Sugihartini N, Ikhsanudin A. Optimization of the composition of Tween 80 and Span 80 as emulsifiers in the essential oil repellant of Sere leaves (Cymbopogon citratus (D.) Stapf) against female Aedes aegypti mosquitoes on the basis of vanishing cream with the simplex lattice design method. Pharmacy. 2012;2:41-54.

17. Chan CC, Lee YC, Lam H, Zhang XM, editors. Analytical method validation and instrument performance verification. NJ: Wiley; 2004.

18. Anonymous. AOAC peer verified methods program, manual on policies and procedure. USA: AOAC International. Rockville; 1998.

19. Voight R. Pharmaceutical technology textbook. 5nd trans. Noerono. Yogyakarta: Gadjah Mada University Press; 1994.

20. Boddu R, Vadla HC, Prathap VR, Kothamasu U, Rallabandi BC, Gannu R. Development of an in vitro-in vivo correlation for sitagliptin and metformin prolonged-release tablet formulations. Turk J Pharm Sci. 2021;18(2):233-41. doi: 10.4274/tjps.galenos.2020.60863, PMID 33902269. 